\title{
Preface to the thematic special issue on international entrepreneurship in and from emerging economies
}

\author{
Hamid Etemad ${ }^{1}$ \\ Published online: 14 April 2016 \\ (C) Springer Science+Business Media New York 2016
}

On behalf of the Journal of International Entrepreneurship (JIEn), I am delighted to introduce this special thematic issue on the broad theme of International Entrepreneurship in and from Emerging Economies. The initial motivation behind this special issue was to provide an opportunity for scholars to examine the dynamics of internationalization of entrepreneurship in environments that are experiencing, or have experienced, relatively rapid change in economic, institutional, and even sociocultural aspects of their environment(s). Accordingly, the theme of this special issue aspires to respond not only to a relatively rich and underexplored family of topics in increased competitiveness, entrepreneurial response to change, and entrepreneurial internationalization in, and from, emerging and transitional economies, but also to offer a very fertile, if not unique, ground for exploring the impact of environmental change and its consequent influence on entrepreneurial internationalization of firms by deploying competitive strategies not attempted before.

According to Hoskisson and his coauthors, the emerging economies are the newly industrializing economies that have gone through change resulting from liberalization and have adopted market-based policies (Hoskisson et al. 2000). North (1990, 2005) observed that human behavior would be influenced by institutional environment, and the emerging and transitional economies offer the real opportunity to observe the dynamic impact of change on entrepreneurial behaviors in general and internationally oriented entrepreneurs in particular; as such, economies would be traveling through a relatively rapid transition in an observable period of time. The change in orientation, due to liberalization in transitional economies, would likely come from a combination of change in both the national and international environments and entail twofold processes: (1) posing new competitive challenges to the older and established firms still laden with the inertia of the past; and also (2) offering entrepreneurially oriented, competitive, and possibly younger firm openings to exploit the emerging and incipient

Hamid Etemad

hamid.etemad@mcgill.ca

1 McGill University, Montreal, QC, Canada 
opportunities at home and abroad facilitated by liberalization at home and reduction, if not removal, of barriers to internationalization. Therefore, the general theme of entrepreneurship in changing environments potentially offers a fertile ground for scholarly enquiry into entrepreneurial process in open, dynamic, and interactive environments, at home and abroad (i.e., What Etemad (2004) called as "dynamic open complex adaptive system or DOCAS") portraying the evolving interaction between the changing nature of the environments influencing both entrepreneurial and firm's behaviors regarding competition at home and entrepreneurial internationalization abroad, regardless of the initial triggering events and forces and the point and the time of influence. Although such comprehensive study could be difficult and time-consuming, it would be highly incisive and insightful. On the bright side, however, relatively rapid pace of change in transitional economies allows for the comparative-static, and hopefully longitudinal, study of entrepreneurial actions in relation to the changing environmental conditions.

When such evolutionary change, initiated at home or mainly by international markets, fosters entrepreneurial internationalization, involving innovative processes, a likely end-result is higher competitiveness at home followed by successful entry into international markets. This process may also trigger a progressive change in competitive, institutional, and even environmental contexts, demanding exceedingly higher efficiencies from suppliers in order to deliver higher values to their ultimate buyers on a rising trajectory projecting further efficiencies and values ahead, which could be viewed as a virtuous cycle. Conversely, when such virtuous cycles are due to entrepreneurial alertness to change in the prevailing context (Kirzner 1997) underlying opportunities, regardless of the location and the source, the firm's entrepreneurial capital (Keen and Etemad 2011a, b, 2012, 2014) might exert further competitive pressures and foster incremental competitive, environmental, and institutional change at home and consequently deliver higher values to all markets. This view resonates with Khanna and Palepu (1997: 42) suggesting that "the most important criterion to define emerging economy is how well an economy helps buyers and seller come together" to conduct increasingly more efficient transactions. However, the rapid pace of globalization and technological change in the past two to three decades, necessitating equally rapid liberalization, may have created institutional voids (Khanna and Palepu 2013) in these economies resulting in increased transaction costs as opposed to promoting economic efficiencies. Generally, liberalization reduces barriers to mobility and offers higher openness to the presence of competitive international firms for not only competing in the local markets, but also taking advantage of relatively efficient local suppliers' lower costs to raise the efficiency of their own international supply chains. The end-result of international entries is higher efficiencies in the local markets, thus forcing the less competitive firms to wither away and the globally competitive firms to flourish faster. However, the rising transaction costs (e.g., due to institutional voids) are theoretically counterproductive and could dampen the pace or the extent of evolutionary change. As a result, the local markets may not achieve high competitiveness, nor could firm's independent internationalization efforts advance as fast, but collaborative participation in the value chain of others (e.g., as suppliers) results in higher scale economies and might override seemingly insurmountable barriers, especially for smaller and resource-constrained firms. To survive the more competitive and demanding environments, the larger firms suffering from the burden of the pre-transition need innovative intrapreneurship to transform themselves. The collaborative 
internationalization of their supply chains (or inward internationalization) has been an effective strategy in the past. In contrast, the smaller entrepreneurial firms' internationally oriented entrepreneurs could take advantage of the larger international market opportunities made possible by the transitional change. Consequently, not only one can develop a perspective on transitional processes and their impacts on entrepreneurship, intrapreneurship, and entrepreneurial internationalization but also observe the impact of institutional change and the transitions' dynamic effects on the older entrenched firms and on the innovative, smaller, and younger firms, all in a relatively short time periods. From an international entrepreneurship perspective, the about arguments suggest a testable hypothesis that the older and larger firms would internationalize slower (and possibly by inward internationalization first), while the smaller entrepreneurial firms would internationalize outwardly and much faster, further enabling us to study the much-ignored impact of dynamic temporal processes.

In short, the articles in this thematic issue offer us the opportunity of observing the interaction and the inner dynamics of three profound sets of processes: (1) the transitional and institutional change resulting in the relative transformation and possible decline of larger and slow-changing firms and institutions; (2) the rapid ascendance of the entrepreneurial efforts resulting in the birth of new and innovative firms aspiring to compete at home and flourishing in international markets; and (3) the action-reaction dynamics of domestic and international competitors involved in the unfolding change. Furthermore, the transition from the traditional to newly emerging institutional environment should also allow for a side-by-side comparative study of conditions that provide entrepreneurial opportunities not available before, in both the older and younger firms. In the older and larger traditional firms, de-internationalization may help them to survive the institutional change; while entrepreneurial internationalization in younger firms may put them on the path of becoming Born Globals, INVs, rapidly internationalizing enterprises (RIEs) (Keen and Etemad 2011a, 2014), and even become progressive socially oriented institutions. Although the limitations of time and space make it difficult to cover all of the above issues, the journal hopes that this issue stimulates research and encourages other researchers to expand upon the impact of similar transitional force arising from the actions, reactions, or inactions of the changedriven strategies associated with transition, such as possible dissolution of older and rent-seeking business groups and formation of international alliances and networks capable of giving rise to increasing competitiveness, bridging institutional voids, creating competitive gaps and chasms to foster entrepreneurial and social-engineering opportunities in firms, institutions, and global environments. Finally, we hope that the articles of this issue stimulate the reader's interest and curiosity in advancing research in following up the above theme and allied topics.

\section{References}

Etemad H (2004) International entrepreneurship as a dynamic adaptive system: towards a grounded theory. J Int Entrep 2(1 and 2):5-59

Hoskisson RE, Eden L, Lau CM, Wright M (2000) Strategy in emerging markets. Acad Manag J 43:249-267

Keen CH, Etemad H (2011a) Rapidly-growing firms and their main characteristics: a longitudinal study from United States. Int J Entrep Ventur 3(4):344-358 
Keen CH, Etemad H (2011b) The impact of entrepreneurial capital and rapidly growing firms: the Canadian example. Int J Entrep Small Bus 12(3):273-289

Keen CH, Etemad H (2012) Rapid-growth and rapid internationalization of smaller enterprises from Canada. Manag Decis 50(4):569-590

Keen CH, Etemad H (2014) Entrepreneurial capital and internationalization of SMEs based in emerging economies. In: Chrysostome E, Molz R (eds) Building Businesses in Emerging and Developing Countries: Challenges and Opportunities. Routledge, London, pp 71-91

Khanna T, Palepu KG (1997) Why focused strategies may be wrong for emerging markets. Harv Bus Rev 75(4):41-51

Khanna T, Palepu KG (2013) Winning in emerging markets: a road map for strategy execution. Harvard Business Press, Boston

Kirzner IM (1997) Entrepreneurial discovery and the competitive market process: an Austrian approach,”. J Econ Lit 35:60-85

North D (1990) Institutions, institutional change, and economic performance. Cambridge University Press, New York

North D (2005) Understanding the process of economic change. Princeton University, Press, Princeton 